\title{
Tri Hita Karana Culture as Moderating the Influence of Good Corporate Governance Principles
}

\author{
Ni Nengah Sri Ekayani ${ }^{1}$ I Made Andika Pradnyana Wistawan ${ }^{2}$ I Nyoman Sutapa ${ }^{1}$ Ni Ketut Sri Ayu Adnyani ${ }^{1}$ \\ 1. Accounting Department, Faculty of Economics, Warmadewa University, Indonesia \\ 2. Accounting Department, Faculty of Economics \& Business, Udayana University, Indonesia
}

\begin{abstract}
One rural financial institution that is currently developing, especially in Bali, is the Village Credit Institution (LPD). LPD performance is the achievement of an organization and contains several things such as the existence of certain targets achieved. An increase in organizational performance that has an impact on achieving the goals of the organization must be supported by the existence of good corporate governance. The application of the principles of Good Corporate Governance is very necessary in running a business. To maximize performance in an organization, an organization basically must also have the view that its performance is influenced by good values derived from the power of Balinese cultural philosophy Tri Hita Karana. The object of this study used 35 LPD in all Denpasar LPD. The results show that the principles of good corporate governance can improve the performance of LPD. Other research results also show that the Tri Hita Karana culture weakens the relationship between the principles of good corporate governance on performance.
\end{abstract}

Key Words: Good Corporate Governance, Performance, Tri Hita Karana, LPD

DOI: $10.7176 /$ RJFA/10-24-18

Publication date: December $31^{\text {st }} 2019$

\section{Introductions}

The LPD has assumed a function to encourage the economic development of the community through targeted savings, as well as effective capital distribution. In addition, the LPD also serves to create equity and provide employment opportunities for rural residents, both those who can work directly at the LPD, and those that can be accommodated by the productive efforts of the community sourced from LPD funding.

In general, LPD can be said to be successful in carrying out their functions and objectives, but this success is not felt by all existing LPD. In practice, there are still many LPD that experience problems both in technical matters such as the problem of bad loans and the inability of LPD to fulfill their obligations to pay debts to existing creditors, even some LPD have gone bankrupt.

Increasement from organisational performance that impact on the achievement of the aims of the organization needs to be supported by of a good corporate governance. Principle of good corporate governance needed in running a business. Fifth that principle of them are watchdog transparency, accountability, responsibility, independency and fairness is the principle which must always be firmly held by any organization who want to realize good governance in it. Although LPD be considered as business having range business only in a village customary, but had to remember that good governance which would provide an advantage better for a business organization.

The application of the principles in good corporate governance is intended to make the LPD more trustworthy and seen as a professional organization based on adat, especially Balinese customs and having the power of an internal control system. In other words, if the trust of the customer and the traditional village community is already owned by an LPD, then the performance of the LPD can be ascertained to increase.

To maximize performance in an organization, an organization basically must also have the view that its performance is influenced by good values derived from self-strength, work environment, and relationships between employees (Adiputra, 2014). Therefore, the influence of local culture is very important, a culture which is already known and always carried out by everyone in the area. A Balinese cultural philosophy Tri Hita Karana which emphasizes on the theory of balance states that Hindu society tends to understand themselves and their environment as a system that is controlled by the value of balance, and manifested in the form of behavior (Gunawan, 2009).

Tri Hita Karana (THK) is a Balinese local wisdom that is used as the foundation of individuals and organizations in each of their activities, especially the traditional village communities who are the owners of LPD. The concept of life that emphasizes the principles of togetherness, harmony and balance between economic goals, 
environmental and cultural preservation, aesthetics and spirituality (Tenaya, 2007). Business activities carried out by the LPD must be based on a cultural values that make this activity useful not only to the people involved in the organization, but also to the surrounding environment and the entire universe. THK provides the view that people tend to view themselves and their environment as a system that is controlled by balance.

THK has the concept that harmonious relationships are important in carrying out an activity or organization. This belief in the balance of harmony has become the guidance of the Balinese people to behave which gave birth to a variety of concrete actions namely (a) the harmonious relationship between humans and Hyang Widhi (God Almighty) known as Parahyangan, (b) the harmony of relations with fellow human beings known as the term Pawongan, and (c) alignment of human relations with the universe known as Palemahan. The essence and essence of THK teaching is good cooperation and harmony of all components related to an activity or organization.

Several studies suggest that THK culture has an influence on the performance of a company including Riana (2010) and Surya et al. (2014) found that THK culture had a positive effect on business performance. Whereas in terms of THK culture is used as a moderating variable, there are differences in the results of research between Adiputra (2014) which states that THK culture moderates the influence of task complexity on internal auditor performance in the Bali Provincial Inspectorate Office while Mustikayani and Dwirandra (2016) get results that THK culture does not can moderate the effect of task complexity on auditor performance.

This is what underlies THK's culture as a moderating variable on the influence of the relationship between GCG and LPD performance. In addition, it is also supported by the Bali Provincial Government program that organizes the Tri Hita Karana Awards which increasingly foster a sense of being able to implement the teachings of THK in everyday life, especially work (Mustikayani and Dwirandra, 2016).

\section{Literature Review}

\subsection{Agency Theory}

The theory that forms the basis of this writing is the agency theory. Jensen and Meckling (1976) stated that agency theory is a situation where one or more people (principals) govern others (agents) to carry out a service on behalf of the principal and authorize the agent to make the best decision for the principal. In this study, the principal is those who become customers of the LPD and the Pakraman village community who demand maximum performance from the agents who are the LPD chairpersons and all staff working in the LPD.

This study examines how GCG can affect the performance of an LPD with the THK culture as its moderating variable. Agency theory assumes that LPD customers and Pakraman villagers are principals who demand the chairman and all LPD staff as agents to maximize their performance in order to align the objectives between the principal and the agent. GCG in this case acts as a tool used by the principal to minimize the occurrence of agency conflicts that can harm the organization later.

\subsection{Good Corporate Governance}

Good Corporate Governance is defined as a set of rules that establish the relationship between shareholders, management, creditors, government, employees and other internal and external stakeholders in relation to their rights and obligations, or in other words a system that directs and controls the company (FCGI, 2003).

Good Corporate Governance is defined as the ways in which corporate management is responsible for its shareholders. Decision makers in the company must be accountable and the decision is able to provide added value to other shareholders.

\subsection{Tri Hita Karana}

In terms of Tri Hita Karana comes from Sanskrit, Tri, which means three, Hita which means happy, and Karana which means cause. Then Tri Hita Karana can be interpreted as the three causes of happiness. Therefore, Tri Hita Karana can provide guidance on how humans must behave towards three things; human relations with God Almighty (parahyangan), human relations with humans (pawongan), and human relations with the environment (palemahan) so that humans can achieve sustainable prosperity (Agung, 2004).

Tri Hita Karana culture is a philosophy or often referred to as the philosophy of Balinese Hindu society (Dwirandra, 2011). As a philosophy, it is often said that THK is an abstract philosophy that cannot be measured. In reality THK has been applied in all social systems and basically can be measured. Windia and Dewi (2007) stated that THK is basically a universal philosophy that essentially exists and is embraced by other communities 
even though it is not Hindu, but only in Bali is there a social system that is real and conscious of applying that philosophy. The philosophy is also very relevant to business or business activities.

\subsection{Village Credit Institution (LPD)}

Village credit institutions are economic institutions that are used for depositing funds and exchanging money in the countryside. According to the Bali Provincial Regulation No. 4 of 2012 concerning the Second Amendment to the Bali Provincial Regulation No. 8 of 2002 concerning Village Credit Institutions, Village Credit Institutions are financial institutions owned by Pakraman village located in the village of Pakraman. Therefore, the handling of this institution itself must be supervised, because it is a financial institution at the most basic level of the region, namely the village. To achieve the planned goals, the Village Credit Institution carried out a lot of innovations from starting to raise funds from village manners, as well as providing capital assistance to village dwellers who needed venture capital.

\subsection{Good Corporate Governance on LPD performance}

Good corporate governance is an important factor in determining the value of the company and influencing the performance of companies such as LPD. Although LPD can be said to be a business that has reach only in one traditional village, it must be remembered that good governance or good corporate governance will provide more benefits for a business organization. The application of the principles of good corporate governance is intended to make the LPD more trustworthy and seen as a professional organization based on adat, especially Balinese customs and having the power of an internal control system. Rahmatika et al. (2015) states that the principles of good corporate governance have a positive effect on the financial performance of PT. Angkasa Pura II (Persero). Similarly, Pradnyaswari and Putri (2016) stated that the principles of good corporate governance have a positive effect on the financial performance of cooperatives in Klungkung Regency.

\section{$\mathrm{H}_{1}$ : Good Corporate Governance has a positive effect on LPD performance}

\subsection{Tri Hita Karana Culture moderates the influence of the principles of Good Corporate Governance on LPD Performance}

Tri Hita Karana stated that people tend to view themselves and their environment as a system that is controlled by the value of balance, and manifested in the form of behaviors such as always wanting to adapt themselves and their environment, so that the impression that they are strong and can maintain patterns, but also easy to adapt, and always want to create inner peace and balance with the environment (Gunawan, 2011). In Mustikayani and Dwirandra (2016) THK culture is not able to moderate the influence of task complexity on auditor performance, but THK culture is able to moderate the influence of time pressure on auditor performance.

The results of the study stating that THK culture can moderate is Adiputra (2014) which states that THK culture can moderate the influence of task complexity on the performance of internal auditors in the Inspectorate Office in Bali Province. When linked to the relationship between GCG and the performance of an LPD, THK culture can be said to be a variable that can weaken the relationship between the two variables. This is due to the existence of THK's culture that existed long before the GCG principle was implemented. In other words, if the application of the THK culture to an LPD is going well, the implementation of the GCG principles will not affect the performance of an LPD. Vice versa, if the THK culture is not practiced properly on an LPD, the application of the GCG principle can greatly affect the performance of the LPD.

\section{$\mathrm{H}_{2}$ : THK weakens the influence of good corporate governance principles on the performance of LPD in} Denpasar City

\section{Methodology}

\subsection{Population and Sample}

The population used in this study is LPD in Denpasar City. The sampling technique used was purposive sampling technique. Data collection method used is a questionnaire survey method. The data analysis technique used in this study is multiple linear regression analysis.

This research was conducted at the Village Credit Institution (LPD) located in Denpasar City. The number of LPD in Denpasar City is 35 (thirty-five) in 4 sub-districts, namely Denpasar Selatan, Denpasar Utara, Dempasar Timur, Denpasar Barat. Now LPD plays an important role for traditional village communities, especially in Denpasar which is the capital city which has very rapid economic growth.

\subsection{Variables and Measurements}

The operational definition of variables in this study is a number of questions in the questionnaire adopted from Atmadja's research questionnaire et al. (2014), relates to variables to be measured: 
Table 3.1 Indicator Variable

\begin{tabular}{|c|c|c|}
\hline No. & Variable & Indicator \\
\hline \multirow{5}{*}{1.} & \multirow{5}{*}{$\begin{array}{l}\text { Good Corporate } \\
\text { Governance }\end{array}$} & $\begin{array}{l}\text { Transparency (X1.1) The LPD announces information about } \\
\text { cooperation with other parties / other banks. }\end{array}$ \\
\hline & & $\begin{array}{l}\text { Accountability (X1.2) Procedures for withdrawing LPD credit } \\
\text { in accordance with the customer's needs plan. }\end{array}$ \\
\hline & & Accountability (X1.3) LPD provides a Legal Lending Limit \\
\hline & & $\begin{array}{l}\text { Independence (X1.4) The LPD uses expert / competent } \\
\text { personnel in every part of its performance. }\end{array}$ \\
\hline & & $\begin{array}{l}\text { Fairness (X1.5) LPD customers are treated with respect, } \\
\text { through quality service. }\end{array}$ \\
\hline \multirow{3}{*}{2.} & \multirow{3}{*}{ Tri Hita Karana } & $\begin{array}{l}\text { Parahyangan (X2.1) The success of carrying out services in } \\
\text { LPD to customers is not solely due to our own abilities, but also } \\
\text { the will of God. }\end{array}$ \\
\hline & & $\begin{array}{l}\text { Pawongan (X2.2) Considering and respecting each other among } \\
\text { employees in carrying out LPD services is an attitude that needs } \\
\text { to be maintained. }\end{array}$ \\
\hline & & $\begin{array}{l}\text { Palemahan (X2.3) The LPD avoids any conflict with the } \\
\text { surrounding community related to environmental problems in } \\
\text { carrying out the task. }\end{array}$ \\
\hline \multirow{4}{*}{3.} & \multirow{4}{*}{ Performance $(\mathrm{Y})$} & $\begin{array}{l}\text { Quality (Y1.1) Skills owned in accordance with the work that } \\
\text { LPD needs. }\end{array}$ \\
\hline & & $\begin{array}{l}\text { Quantity (Y1.2) The level of achievement of LPD work volume } \\
\text { results in compliance with the company's expectations. }\end{array}$ \\
\hline & & $\begin{array}{l}\text { Reliability (Y1.3) The LPD is compliant with all work rules and } \\
\text { procedures established in a job. }\end{array}$ \\
\hline & & $\begin{array}{l}\text { Accuracy (Y1.4) LPD works in accordance with the corridors } \\
\text { of the company's organizational structure }\end{array}$ \\
\hline
\end{tabular}

\section{Results and Discussion}

\subsection{Research Respondents}

The data obtained in this study is by distributing questionnaires to Village Credit Institutions (LPD) in Denpasar City. LPD who are willing to receive and fill out questionnaires as many as 35 respondents from 35 LPD in Denpasar City. The distribution of questionnaires and data collection took three weeks.

\subsection{Validity Test}

Validity testing uses the Product Moment technique at a significant level of 5 percent. Can be seen in table 4.1 as follows: 
Table 4.1

\section{Validity Test}

\begin{tabular}{|l|c|c|c|}
\hline \multicolumn{1}{|c|}{ Statements } & $\begin{array}{c}\text { Coefficients } \\
\text { Correlation }\end{array}$ & Sig. & Validity \\
\hline Good Corporate Governance & Valid \\
\hline 1. (X1.1) & 0,378 & 0,25 & Valid \\
\hline 2. (X1.2) & 0,656 & 0,00 & Valid \\
\hline 3. (X1.3) & 0,650 & 0,00 & Valid \\
\hline 4. (X1.4) & 0,684 & 0,00 & Valid \\
\hline 5. (X1.5) & 0,335 & 0,49 & Valid \\
\hline Tri Hita Karana & \multicolumn{5}{|l|}{0} \\
\hline 1. (X2.1) & 0,518 & 0,01 & Valid \\
\hline 2. (X2.2) & 0,625 & 0,00 & Valid \\
\hline 3. (X2.3) & 0,760 & 0,00 & Valid \\
\hline LPD Performance & 0,739 & 0,00 & Valid \\
\hline 1. (Y3.1) & 0,743 & 0,00 & Valid \\
\hline 2. (Y3.2) & 0,652 & 0,00 & \\
\hline 3. (Y3.3) & 0,713 & 0,00 & \\
\hline 4. (Y3.4) & \multicolumn{5}{|l}{} \\
\hline
\end{tabular}

Table 4.1 shows that all correlation coefficients of the indicator variables tested are greater than $0.30(\mathrm{r}>0.3)$. This shows that all indicators of good corporate governance, Tri Hita Karana culture and LPD performance found in this study proved valid.

\subsection{Reliability Test of Research Instruments}

Reliability testing is used to measure the consistency of a variable in the study. The instrument is said to be reliable for measuring variables when they have values (Cronbach's Alpha>0.60). Reliability test results can be seen in table 4.2 .

Table 4.2

\section{Reliability Test}

\begin{tabular}{|l|c|c|}
\hline \multicolumn{1}{|c|}{ Variabel } & Cronbach's Alpha & Reliability \\
\hline Good Corporate Governance & 0,782 & Reliable \\
\hline Tri Hita Karana & 0,810 & Reliable \\
\hline LPD Performance & 0,737 & Reliable \\
\hline
\end{tabular}

Table 4.2 shows that each Cronbach's Alpha value for each instrument is greater than 0.6 (Cronbach's Alpha> 0.60). This shows that the variables of Good Corporate Governance, Tri Hita Karana Culture and LPD Performance are reliable, so they can be used to conduct research.

\subsection{Moderation Regression Analysis}

Moderation regression analysis is used to test whether tri hita karana culture weakens the GCG principle on LPD performance. In addition, the moderation regression analysis also proves the hypothesis of a positive relationship between the principles of good corporate governance on company performance shown in table 4.3 as follows: 
Table 4.3

\section{Moderation Regression Analysis}

\begin{tabular}{|l|c|c|}
\hline \multicolumn{1}{|c|}{ Model } & $\mathrm{t}$ & Sig. \\
\hline Constant & 1,451 & 0,156 \\
\hline GCG & 4,356 & 0,000 \\
\hline Constant & 1,480 & 0,149 \\
\hline GCG & 4,327 & 0,000 \\
\hline THK & $-0,576$ & 0,569 \\
\hline Constant & 1,072 & 0,292 \\
\hline GCG & 4,981 & 0,000 \\
\hline THK & 0,032 & 0,975 \\
\hline GCG*THK & $-2,086$ & 0,045 \\
\hline
\end{tabular}

The first hypothesis (H1) states that Good Corporate Governance has a positive effect on LPD performance. Based on table 5.12 it can be seen that the variable user involvement in the development of SIA has a significance value of 0.00 . The higher the Good Corporate Governance, the higher the LPD Performance implies. Conversely, the lower the Good Corporate Governance causes the lower LPD Performance.

Good corporate governance is an important factor in determining the value of the company and influencing the performance of companies such as LPD. Although LPD can be said to be a business that has reach only in one traditional village, it must be remembered that good governance or good corporate governance will provide more benefits for a business organization. The application of the principles of good corporate governance is intended to make the LPD more trustworthy and is seen as a professional organization based on adat, especially Balinese customs and has the power of an internal control system. Rahmatika et al. (2015) states that the principles of good corporate governance have a positive effect on the financial performance of PT. Angkasa Pura II (Persero). Similarly, Pradnyaswari and Putri (2016) stated that the principles of good corporate governance have a positive effect on the financial performance of cooperatives in Klungkung Regency.

The second hypothesis (H2) states that tri hita karana culture weakens the relationship between Good Corporate Governance and LPD Performance. Based on table 5.12 it can be seen that the tri hita karana cultural interaction variable with Good Corporate Governance has a significance value of 0.00 . The higher the tri hita karana cultural interaction with Good Corporate Governance implies the higher the LPD Performance. On the contrary, the lower the tri hita karana cultural interaction with Good Corporate Governance causes the lower LPD Performance.

Tri Hita Karana stated that people tend to view themselves and their environment as a system that is controlled by the value of balance, and manifested in the form of behaviors such as always wanting to adapt themselves and their environment, so that the impression that they are strong and can maintain patterns, but also easy to adapt, and always want to create inner peace and balance with the environment (Gunawan, 2011). In Mustikayani and Dwirandra (2016) THK culture is not able to moderate the influence of task complexity on auditor performance, but THK culture is able to moderate the influence of time pressure on auditor performance.

The results of the study are consistent with the research conducted by Adiputra (2014) which states that THK culture can moderate the influence of task complexity on the performance of internal auditors in the Inspectorate Office in Bali Province. When linked to the relationship between GCG and the performance of an LPD, THK culture can be said to be a variable that can weaken the relationship between the two variables. This is due to the existence of THK's culture that existed long before the GCG principle was implemented. In other words, if the application of the THK culture to an LPD is going well, the implementation of the GCG principles will not affect the performance of an LPD. Vice versa, if the THK culture is not practiced properly on an LPD, the application of the GCG principle can greatly affect the performance of the LPD. 


\section{Conclusion and Suggestion For Research}

\subsection{Conclusion}

Based on the results of data analysis and discussion, the conclusion of hypothesis 1 is that there is a positive influence between Good Corporate Governance on the Performance of LPD in Denpasar. Hypothesis 2 shows that there is a negative influence between the interaction of Tri Hita Karana Culture and Good Corporate Governance on the Performance of LPD in Denpasar city. The negative influence can be interpreted that the tri hita karana culture weakens the relationship between Good Corporate Governance to the Performance of LPD in Denpasar city.

\subsection{Suggestion}

Based on the conclusions above, where Good Corporate Governance has a positive effect on the performance of the LPD and tri hita culture, it weakens the relationship between Good Corporate Governance and the Performance of LPD in Denpasar, so the following suggestions can be expressed:

1) The Chair of the LPD should pay more attention to the tri hita karana culture in the LPD work environment. Tri hita karana culture which weakens LPD performance is one of the factors that need serious attention so that LPD performance can be improved.

2) Future research is expected to consider the use of other cultural variables. Variables that are considered in the form of the culture of Punia funds or the Pusura Artha chess culture.

\section{Reference}

Adiputra, I Made Pradana. 2014. Budaya Tri Hita Karana Sebagai Pemoderasi Pengaruh Kompleksitas Tugas terhadap Kinerja Internal Auditor (Studi Pada Kantor Inspektorat di Provinsi Bali). Jurnal Dinamika Akuntansi. Vol. 6. No. 2. pp. 191-206.

Adnyana, Prajuru. 2016. "Tri Hita Karana dalam Agama Hindu”. http://babadbali.com/canang-sari/2016/tri-hitakarana-dalam-agama-hindu/. Diunduh tanggal 21 Juli 2016. 16.60 Wita.

Agung, A.A.G. 2004. Tri Hita Karana. Kompas. Diunduh tangggal 30 Agustus 2016. 20.00 Wita.

Ahmed, Esra dan Allam Hamdam. 2015. The Impact of Corporate Governance on Firm Performance: Evidence from Bahrain Stock Exchange. European Journal of Business and Innovation Research. Vol. 3. No. 5. pp. 25-48.

Ashrama, Berata. 2005. "Implementasi Konsep Tri Hita Karana pada Beberapa Hotel di Bali". (thesis). Denpasar: Universitas Udayana.

Astawa Putu, Sudarma made, Siti Aisjah dan Djumahir. 2012. Credit Risk and Harmonious Values Practice (Study at Village Credit Institution (LPD)) of Bali province. Journal of Business and Manajemen. Vol.6, No. 4, pp. 16-20.

Astawa Putu, Sudarma made, Siti Aisjah dan Djumahir. 2013. Institutional Ownership and Harmonious Values in Increasing Financial Performance of Village Credit Institution (LPD). Journal of Basic and Applied Scientific Research. Vol.3, No.6,pp. 813-824.

Atmadja, Anantawikrama Tungga, Nyoman Ari Surya Darmawan dan Komang Adi Kurnia Saputra. 2014. Pengaru Implementasi Good Corporate Governance dan proteksi Awig-Awig terhadap Kinerja Lembaga Perkreditan Desa (LPD) dengan Budaya Menyama Braya sebagai Variabel Moderasi. www.multiparadigma.lecture.ub.ac.id. Diunduh tanggal 24 Mei 2016. 17.50 Wita.

Bistrova, J. and Lace, N. 2012. Dividend policy determinants in CEE countries, in Contemporary Issues in Business. Management and Education'2012.pp. 69-78.

Budiarti, I. 2010. Penerapan Prinsip-prinsip Good Corporate Governance Pada Dunia Perbankan. Jurnal Manajemen, 8 .

Chen, et al. 2005. An empirical investigation of the relationship between intellectual capital and firm's market value and financial performance. Journal of Intellectual Capital, Vol.6, No.2.

Dabor, Alexander Olawumi, David T. Isiavwe, Muribav Akintunde Ajagbe and Adunola Oluremi Oke. 2015. Impact of Corporate Governance on Firm's Performance. International Jorunal of Economics, Commerce and Manajement. Vol. 3. No. 6.

Dar, Laib A. Muhammad Akram Naseem, Ramiz Ur Rehman and Dr. G.S.K. Niazi. 2011. Corporate Governance and Firm Performance a Case Study of Pakistan Oil and Gas Companies Listed in Karachi Stock Exchange. Global Journal of Management and Business Research. Vol. 2. No. 8. 
Dewi, Kadek Krismaya dan IGA M Asri Dwijaputri. 2014. Pengaruh Penerapan Prinsip-Prinsip GCG pada Kinerja Keuangan Lemaba Perkreditan Desa Kabutan Gianyar, Provinsi Bali. E-jurnal akuntansi Universitas Udayana. Vol. 8.1. pp. 70-82.

Dharmanegara, Ida Bagus Agung, Made Sudarma, Noermijati and Solimun. 2013. Effect of Spiritual Intellegence and Asta Brata Leadership to the Culture of Tri Hita Karana and Employment Performance (Study at Rutal Credit Institution in Badung regency of Bali Province). Journal of Business and Manajement. Vol.11. pp.05-12.

Dwirandra, A.A.N.B. 2011. "Rekontruksi Metoda Penilaian Aset dengan Filosofi Tri Hita Karana". (Disertasi). Malan: Universitas Brawijaya.

Eisenhardt, Kathleem. (1989). Agency Theory: An Assesment and Review. Academy of Management Review 14. pp. 57-74.

Emile, Rimon, Aiman Ragab and Sandy Kyaw. 2014. The Effect of Corporate Govermamce on Firm Performance, Evidence from Egypt. Asian Aconomic and Financial Review. Vol. 4. No. 12. pp. $1865-$ 1877.

Ghozali, Imam. 2009. Aplikasi Analisis Multivariate dengan program SPSS. Semarang: Badan Penerbit Universitas Diponegoro.

Gunawan, Ketut. 2009. "Pengaruh Budaya Organisasi,Kepuasan Kerja dan Motivasi Kerja terhadap Gaya Kepemimpinan dan Kinerja Organisasi (Studi pada Lembaga Perkreditan Desa (LPD) di Bali)". (Disertasi) Malang: Universitas Brawijaya,

Gunawan, Ketut. 2011. Peranan Falsafah Tri Hita Karana Bagi Pertumbuhan dan Kinerja Lembapa Perkreditan Desa (LPD) di Bali. Jurnal Analisis Manajemen. Vol.5, No.2, pp. 23-36.

Guo, Zhaoyang and Udaya Kumara KGA. 2012. Corporate Governance and Firm Performance of Listed Firm in Sri Lanka. Procedia. Vol 40. pp. 664-667.

Hasibuan, Malayu. 2013. Manajemen Sumber Daya Manusia. Cetakan Ketujuh Belas. Jakarta: Bumi Aksara.

Haque, F., Arun, T., \& Kirkpatrick, C. 2008. Corporate Governance and Capital Markets: A conceptual framework. White paper, Heriot-Watt University.

Herlina. 2013. "Pengaruh Return On Capital Employed (ROCE), Return On Asset (ROA), Dan Return On Equity (ROE) Terhadap Earnings Per Share (EPS) Pada Perusahaan Manufaktur Yang Terdaftar Di Bursa Efek Indonesia" (tesis). Medan. Universitas Sumatera Utara.

Ikhsan, A dan Ishak, M. 2005. Akuntansi Keperilakuan. Jakarta: Salemba empat.

Indriantoro, Nur dan Supomo, Bambang. 2013. Metodologi Penelitian Bisnis Untuk Akuntansi \& Manajemen Edisi Pertama.Yogyakarta:BPFE - Yogyakarta.

Jensen, M. C and Meckling, W.H. 1976. Theory of the Firm : Managerial Behavior, Agency Costs and Ownership Structure. Journal of Financial Economics. Vol:3, No.4, pp. 305-360.

Jogiyanto, 2007. Sistem Informasi Keperilakuan. Edisi Revisi. Yogyakarta: Andi Offset.

Komite Nasional Kebijakan Governance (KNKG). 2006. Pedoman Umum Good Corporate governance Indonesia, Jakarta.

Kumalasari, P.D dan Astika, I.B.P. 2013. Pengaruh Modal Intelectual Pada Kinerja Keuangan Di Bursa Efek Indonesia. Journal Fakultas Ekonomi dan Bisnis Universitas Udayana. Vol. 02. No. 05.

Laporan Pembina Lembaga Perkreditan Desa Kota (PLPDK) Denpasar per Agustus 2012.

Luthans, Fred, 2005. Perilaku Organisasi. (Vivin Andhika Yuwono, Shekar Purwanti, Arie Prabawati, dan Winong Rosari, Pentj).Yogyakarta: Penerbit Andi.

Mangkunegara, Anwar Prabu. 2005. Sumber Daya Manusia perusahaan. Bandung: Remaja Rosdakarya.

Martha, W. 2014. "Pengaruh Transparansi Dan Akuntabilitas Terhadap Kinerja Instansi Pemerintah Pada Dinas Di Kota Bandung (Survey diInstansi Pemerintah Kota Bandung)". (dissertation). Bandung: Universitas Widyatama.

Mohammed and Fatimoh. 2012. Impact of Corporate Governance on Banks Performance in Nigeria. Journal of Emerging Trends in Economic and Management Sciences. Vol. 3. No. 3. pp. 256-260.

Mustikayani, Ni Luh Putu Desy dan A.A.N.B. Dwirandra. 2016. Budaya Tri Hita Karana Sebagai Pemoderasi Kompleksitas Tugas dan Tekanan Waktu terhadap Kinerja Auditor. E-jurnal Akuntansi Universitas Udayana. Vol. 16.2. pp. 1544-1573. 
Peraturan Daerah Provinsi Bali No. 8 Tahun 2002 tentang Lembaga Perkreditan Desa.

Peraturan Daerah Provinsi Bali Nomor 4 Tahun 2012 tentang Perubahan Kedua Atas Peraturan Daerah Provinsi Bali Nomor 8 Tahun 2002 tentang Lembaga Perkreditan Desa.

Permana, Angga. 2010. "Pengaruh Total Quality Management (TQM) Terhadap Kinerja Keuangan Pada PT. Sipatex Putri Lestari Bandung" (tesis). Unikom. Bandung.

Pitana, I Gede. 2002. Kebijakan dan Strategi Pemerintah Daerah Bali dalam Pembangunan Pariwisata. Pada Seminar Nasional Pariwisata Bali the Last or the Lost Paradiseî. Pembangunan Pariwisata yang Berkelanjutan. Denpasar: Universitas Udayana.

Pradnyaswari, Luh Gede Diah Ary dan I Gusti Ayu Made Asri Dwija Putri. 2016. Pengaruh Prinsip-Prinisp Good Corporate Governance pada Kinerja Keuangan Koperasi di Kabupaten Klungkung. E-jurnal Akuntansi Universitas Udayana. Vol. 14. No. 2. pp. 1064-1091.

Rahmatika, N., Kirmizi, dan Agus, R. 2015. Pengaruh Penerapan Prinsip-Prinsip Good Corporate Governance Terhadap Kinerja Keuangan Perusahaan (Studi pada PT Angkasa Pura II). Jurnal Akuntansi (Media Riset Akuntansi dan Keuangan). Vol. 3. No. 2. pp.148-156.

Renders, Annelies, Ann Gaerumynck and Pier Sercu. 2010. Corporate Governance Ratings and Company Performance: A Cross-European Study. Corporate Governance: An International Review. Vol. 18. No. 2. pp. 87-106.

Riana, I Gede. 2010. "Dampak Penerapan Budaya Tri Hita Karana terhadap Orientasi Kewirausahaan dan Orientasi Pasar serta Konsekuensinya pada Kinerja Usaha dengan Moderator Pembelajaran Bisnis" (disertasi). Malang: Universitas Brawijaya.

Rivai Veithzal, Ahmad Fawzi, Ella Jauvani Sagala, dan Silviana Murni. 2011. Performance Appraisal. Jakarta: PT. Raja Grafindo Persada.

Setyawan, Komang Meitradi dan I Gusti Ayu Made Asri Dwija Putri. 2013. Pengaruh Good Corporate Governance terhadap Kinerja Keuangan Lembaga Perkreditan Desa di Kecamatan Mengwi Kabupaten Badung. E-jurnal Akuntansi Universitas Udayana. Vol 5.3. pp. 586-598.

Shleifer, A. dan R.W. Vishny. 1997. A Survey of Corporate Governance. Journal of Finance, Vol 52. No 2. pp. 737-783

Suardikha, I Made Sadha. 2011. "Pengaruh Implementasi Budaya Tri Hita Karana terhadap Penggunaan Sistem Infromasi Akuntansi dimediasi Keyakinan Diri atas Komputer, Keinovatifan Personal, Persepsi kegunaan, dan Persepsi Kemudahan Penggunaan pada Bank Perkreditan Rakyat di Bali” (disertasi). Malang: Universitas Brawijaya.

Suci, Y. F. 2013. Pengaruh Penerapan Prinsip Good Corporate Governance Terhadap Kinerja Perusahaan Pada PT. Kereta Api (Persero) Divisi Regional III Sumatera Selatan. Palembang: STIE MDP.

Sudiyatno, Bambang dan Jati Suroso. 2010. Analisis Pengaruh Dana Pihak Ketiga, BOPO, CAR dan LDR terhadap Kinerja Keuangan pada Sektor Perbankan yang Go Publik di Bursa Efek Indonesia. Dinamika Keuangan dan Perbankan. Vol. 2. No. 2. pp. 125-137.

Sugiono. 2010. Metode Penelitian Bisnis. Cetakan Ke-15. Bandung: CV. Alvabeta.

Sumerta, Dewa. 2016. Aset LPD Kota Denpasar naik 25 persen”. http://beritabali.com/read/2016/05/18/201605180006/Aset-LPD-Kota-Denpasar-Naik-2125Persen.html. Diunduh tanggal 20 Juli 2016. 13.30 Wita.

Surat Edaran Menteri Negara Pasar Modal dan Pengawas BUMN No.S.106/M.P.M.P.BUMN/2000.

Surat Keputusan Direksi PT. Bank Pembangunan Daerah Bali No. 0193.02.10.2007.2 tangga; 5 Juni 2007 tentang Pedoman Sistem Penilaian terhadap Lembaga Perkreditan Desa (LPD)

Surya, Ida Bagus Ketut. 2014. "Pengaruh Budaya Tri Hita Karana terhadap Kinerja Perusahaan dengan Mediasi Kepemimpinan dan Komitmen Organisasional (Studi pada Perusahaan Daerah Air Minum di Provinsi Bali)" (disertasi). Malang: Universitas Brawijaya.

Surya, Ida Bagus Ketut, Armanu Thoyib, Achmad Fatchan dan Mintarti Rahayu. 2014. Tri Hita Karana Culture Effect on Company Performance, Leadership and Organizational Commitment (Studies an Regional Water Company in Bali Province). International Journal of Business and Management Invention. Vol. 3. No. 6. pp. 13-22. 
Tenaya, Gede Agus Indra. 2007. “Analisis Falsafah dan Konsep Akuntansi dalam Perspektif Filsafat Kultur Bali Tri Hita Karana dan Kesadaran Internal Lembaga terhadap Hukum Perusahaan”. (Thesis). Malang: Universitas Brawijaya,

Ulum, I. 2007. "Pengaruh Intellectual Capital terhadap Kinerja Keuangan Perusahaan Perbankan di Indonesia" (tesis). Semarang. Universitas Diponogoro.

Windia, Wayan dan Dewi, Ratna Komala. 2007. Analisis Bisnis yang Berlandaskan Tri Hita Karana, Denpasar: Penerbit Universitas Udayana.

Yuliani. 2007. Hubungan efisiensi operasional dengan kinerja profitabilitas pada sektor perbankan yang go publik di Bursa Efek Jakarta. Jurnal Manajemen \& Bisnis Sriwijaya. Vol. 5, No. 10.

Zarkasyi, Moh. Wahyudin. 2008. Good Corporate Governance. Bandung: Alfabeta. 